\title{
A Comparative Analysis of Translation and Interpretation Tests at Home and Abroad and Its Enlightenment
}

\author{
CHEN Qionglu \\ Henan Institute of Technology, Xinxiang City, China
}

Received: June 16, $2021 \quad$ Accepted: July 12, $2021 \quad$ Published: November 30, 2021

To cite this article: CHEN Qionglu. (2021). A Comparative Analysis of Translation and Interpretation Tests at Home and Abroad and Its Enlightenment. Asia-Pacific Journal of Humanities and Social Sciences, 01: 3, 196-208, DOI: 10. 53789/j. 16530465.2021.0103.022.p

To link to this article: https://doi. org/10.53789/ j. 1653-0465.2021.0103.022.p

The research project entitled "A comparative analysis of Translation and Interpretation Tests at home and abroad and Its Enlightenment Under the Guidance of the First-Class Course" is supported by China Association for Non-Government Education.

Abstract: The translation and interpretation test varies from country to country. This paper compares the translation and interpretation tests in Australia, the United Kingdom, the United States, Canada, Austria, Finland, Ireland, South Africa, Chinese Taiwan and China, and summarizes the similarities and differences in methods, assessment standards, forms and contents, recruitment requirements of assessors, application conditions of the tests. Drawing on the mature mechanism and paradigm of foreign mainstream certification bodies, this will finally act as a possible way of developing the CATTI. And I propose some suggestions in order to make CATTI more sustainable and beneficial to the cultivation of translation and interpretation talents in China.

Keywords: translation and interpretation assessment; certification system; translation and interpretation tests

Notes on the contributor: Chen Qionglu holds a master's degree in English translation. She is a lecturer at Henan Institute of Technology with academic interest in translation and interpretation assessment. Her email address is Chenchengodlen@163.com.

\section{國内外翻譯測試對比分析及啟示}

\author{
陳瓊璐
}

河南工學院

摘 要: 口筆譯資格認證制度因國家而異, 本文對比分析了澳大利亞、英國、美國、加拿大、奥地利、芬蘭、愛爾蘭、南 
非、中國堂灣及我國的翻譯資格測試, 歸納了10 個國家或地區翻譯資格認登方式、評估標準、考試形式和内容、評 估員招募要求、報考條件和申訴, 共 6 方面的異同, 以期通過借鉒國外主流認證機構成熟機制和規模範式, 調整我 國翻譯専業資格(水準)考試(CATTI), 建立可持續發展且益於培養専業翻譯人才的翻譯資格認噔體系。

關鍵词: 翻譯品質評估; 考試認登;口筆譯測試

基金項目: 河南省民辦教育協會 2021 年度課題基金專案: “金課” 建設背景下國内外翻譯水準測試對比分析及啟 示(HNMXL20210239)。

\section{引言}

在全球化背景下,國際交流日益頻繁, 翻譯人才需求逐年上升, 國內出現了一些專門針對翻譯人才的水 準考試, 如上海外語口語證書考試、CATTI 等。對譯者翻譯能力開展有效的測評是保證翻譯服務和翻譯人才 培養品質的重要前提,設計合理的測試可以保證翻譯認證的公平性, 也有助於學校或者社會團體選拔優秀 的翻譯人才。在這一背景下, 翻譯測試如何設計、命題、譯文品質如何評估等問題叒待進一步研究。澳大利 亞、加拿大、美國、英國、芬蘭、奧地利等國家擁有先進的翻譯資格認證體系,學習其先進經驗和行業實踐,有 助於加強翻譯行業管理, 規範翻譯就業市場, 促進翻譯行業人才隊伍建設,科學、客觀、公正地評價翻譯專業 人才水準和能力,使中國翻譯行業更好地與國際接軌,為中國與世界各國政治、經濟、文化、教育等領域的交 流合作提供翻譯人才資源。

翻譯水準測試是對翻譯人員進行資格認證的重要手段,翻譯水準測試指用人單位或認證機構對參加測 試的譯者進行能力評估, 通過測試後會獲得相應證書(分資格證書與能力證書)。目前, 國内學者對世界各 國翻譯資格認證研究主要涉及各國翻譯資格認證對比分析 (任文,2005; 牛寧, 2011; 馮芳,2014; 李雙,錢多 秀,2016; 段兆會,張允,2018; )、翻譯考試中倫理考察 ( 朱雀,2018)、資格證書體系多角度構建 (趙田園, 穆 雷,2019)、CATTI 考試問題與對策(吳萍,崔啟亮,2018)、考試內容設計 (段兆會,2019)、CATTI 與 MTI 銜接 問題 (吳萍,崔啟亮,2018; 姚師平,2019)、實證研究包括翻譯測試的信度、效度問題及檢驗方法(李欣,2004; 江進林,2010; 肖維青,2011)。其中,翻譯資格認證對比分析研究主要聚焦於口譯資格考試品質評價與模式 改革。通過經驗反思,理性思辨或結合測試理論和翻譯考試內容特點,相關學者對翻譯測試模式提出改進 意見。儘管國內一些學者已經對部分國家翻譯資格認證進行對比分析,但很少深人對比分析世界多個國家 或地區翻譯資格認證,並為我國翻譯專業資格 (水準) 考試發展提出細節性建議。他山之石可以攻玉,我國 翻譯專業資格(水準)考試依據中國國情而設立, 語言組合、考試內容和形式、評分等具有中國特色,而歐美 主流翻譯資格認證體系成立時間較早, 體系完善, 操作性強, 與其進行多維度對比分析, 有助於我們瞭解各 國翻譯資格認證的共性和個性,對於提升我國翻譯專業資格認證水準無疑會起到一定推動作用。筆者在對 比分析了全球 15 國家或地區的翻譯資格認證機構的基礎上,選取了 10 個具有可借鑒性意義的國家或地區 的翻譯水準測試進行對比分析, 以期為 CATTI 改革與發展提供參考意見。各國翻譯測試具體異同見下麵表 格( 翻譯測試縱覽見表 1 , 認證方式見表 2 , 報考條件見表 3 , 考試具體內容見表 4 , 翻譯品質評估方法見表 5 , 考試使用工具見表 6 ,評分員任職資格見表 7 , 考前培訓情況見表 8 , 申訴制度見表 9)。 


\section{一、世界各國或地區翻譯資格 (水準) 考試縱覽}

國內外具有代表性的翻譯水準測試具體情況如下:

\begin{tabular}{|c|c|c|c|c|}
\hline $\begin{array}{l}\text { 世界 } \\
\text { 各洲 }\end{array}$ & $\begin{array}{c}\text { 國別 } \\
\text { ( 地區) }\end{array}$ & 證書種類 & 頒發機構 & 影響力 \\
\hline \multirow[b]{3}{*}{ 亞 } & 中國 & $\begin{array}{l}\text { 筆譯 ( Translator) (譯審、一、二、三 } \\
\text { 級)；口譯( Interpreter) (譯審、一、二、 } \\
\text { 三級) }\end{array}$ & 中國外文局 & $\begin{array}{l}\text { 全國翻譯專業資格 (水準) 考試簡稱, } \\
\text { 是受人力資源和社會保障部委託, 由外 } \\
\text { 文局負責實施與管理的一項國家級職 } \\
\text { 業資格考試。 }\end{array}$ \\
\hline & $\begin{array}{l}\text { 臺灣 } \\
\text { 地區 }\end{array}$ & $\begin{array}{l}\text { 教育部中英文翻譯能力檢定考試( The } \\
\text { Chinese and English Translation and In- } \\
\text { terpretation Competency Examinations, } \\
\text { E-CTICE) }\end{array}$ & $\begin{array}{l}\text { 中華民國教育部 ( The } \\
\text { Ministry of Education, } \\
\text { MOE) }\end{array}$ & $\begin{array}{l}2007 \text { 年, 中華民國教育部推出口筆譯 } \\
\text { 能力考試, } 2010 \text { 年,委託語言培訓和測 } \\
\text { 試中心 ( The Language Training and } \\
\text { Testing Center) 實施考試。 }\end{array}$ \\
\hline & $\begin{array}{l}\text { 澳大 } \\
\text { 利亞 }\end{array}$ & $\begin{array}{l}\text { Certified Advanced Translator; } \\
\text { Certified Translator; } \\
\text { Recognized Practicing Translator ( Pro- } \\
\text { visional Interpreter; Provisional Auslan } \\
\text { /deaf/Specialist Health /Specialist } \\
\text { Legal /Conference Interpreter) Certified } \\
\text { Provisional Interpreter; } \\
\text { Certified Provisional Auslan Interpreter; } \\
\text { Certified Provisional Deaf Interpreter; } \\
\text { Certified Provisional Interpreter } \\
\text { Aboriginal and Torres Strait Islander } \\
\text { Languages; } \\
\text { Certified Interpreter; } \\
\text { Certified Auslan Interpreter; Certified } \\
\text { Specialist Health Interpreter; } \\
\text { Certified Specialist Legal Interpreter; } \\
\text { Certified Conference Interpreter. }\end{array}$ & $\begin{array}{l}\text { 澳大利亞翻譯資格認可 } \\
\text { 局 ( National } \\
\text { Accreditation Authority } \\
\text { for Translator and Inter- } \\
\text { preters Ltd, 以下簡稱 } \\
\text { NAATI) }\end{array}$ & $\begin{array}{l}\text { NATTI 得到國際認可原因有很多, 其 } \\
\text { 中最重要的兩點是: 它是一個國家認證 } \\
\text { 機構,對 } 60 \text { 多種國際語言和 } 45 \text { 種土著 } \\
\text { 語言進行認證; 它歸聯邦政府以及所有 } \\
\text { 州和地區政府擁有。很少有國家能夠 } \\
\text { 建立這麼龐大且統一的認證系統。 }\end{array}$ \\
\hline \multirow{2}{*}{$\begin{array}{l}\text { 北 } \\
\text { 美 } \\
\text { 洲 }\end{array}$} & 美國 & Translation Certification Exam & $\begin{array}{l}\text { 美國翻譯家協會 (A- } \\
\text { merican Translator As- } \\
\text { sociation, 以下 簡 稱 } \\
\text { ATA) }\end{array}$ & $\begin{array}{l}\text { 美國影響力最大的國家級別的翻譯協 } \\
\text { 會, 目前全球僅有不到 } 2000 \text { 名成員獲 } \\
\text { 得認證,通過率小於 } 20 \% \text { 。 }\end{array}$ \\
\hline & 加拿大 & $\begin{array}{l}\text { Conference Interpretation Exam; Court } \\
\text { Interpretation Exam; } \\
\text { Terminology Exam; } \\
\text { Translation Exam }\end{array}$ & $\begin{array}{l}\text { 加拿大口筆譯暨術語工 } \\
\text { 作 者 委員 ( Canadian } \\
\text { Translator, } \\
\text { Terminologists and In- } \\
\text { terpreters Council) }\end{array}$ & $\begin{array}{l}\text { CTTIC 成立於 } 1970 \text { 年, 作為翻譯品質 } \\
\text { 和能力的保證, CTTIC 致力於促進專業 } \\
\text { 筆譯、術語和口譯認證, 提高翻譯専業 } \\
\text { 水準。它協調其成員組織的行動, 以確 } \\
\text { 保翻譯行業標準的統一。 }\end{array}$ \\
\hline 歐洲 & 奥地利 & $\begin{array}{l}\text { 認證法庭譯員 ( Certified court interpret- } \\
\text { er) }\end{array}$ & $\begin{array}{l}\text { 奥地利認證法庭譯員協 } \\
\text { 會 ( Austrian Ass - } \\
\text { ociation of Certified } \\
\text { Court Interpreters, 以下 } \\
\text { 簡稱 AACI) }\end{array}$ & $\begin{array}{l}\text { 奥地利目前不存在官方認證考試,該組 } \\
\text { 織承擔奥地利各州宣誓譯員和法庭認 } \\
\text { 證口譯員考試, 目前有 } 600 \text { 多位會員。 }\end{array}$ \\
\hline
\end{tabular}


续表

\begin{tabular}{|c|c|c|c|c|}
\hline $\begin{array}{l}\text { 世界 } \\
\text { 各洲 }\end{array}$ & $\begin{array}{c}\text { 國別 } \\
\text { (地區) }\end{array}$ & 證書種類 & 頒發機構 & 影響力 \\
\hline \multirow{3}{*}{ 歐洲 } & 愛爾蘭 & $\begin{array}{l}\text { 法律翻譯譯員 ( ITIA Certified Legal } \\
\text { Translator) }\end{array}$ & $\begin{array}{l}\text { 愛爾蘭口筆譯協 會 } \\
\text { ( Irish Translators' and } \\
\text { Interpreters } \\
\text { Association, 以下簡稱 } \\
\text { ITIA) }\end{array}$ & 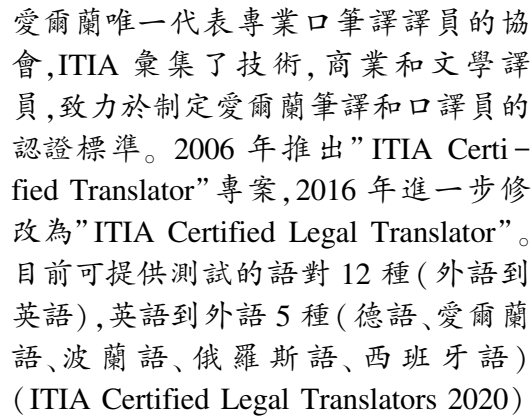 \\
\hline & 芬蘭 & $\begin{array}{l}\text { 授權筆譯員考試 (the Authorized } \\
\text { Translator's Examination) }\end{array}$ & $\begin{array}{l}\text { 芬蘭 國 家教 育局 } \\
\text { ( Finnish National } \\
\text { Agency for Education, } \\
\text { 以下簡稱 EDUFI) }\end{array}$ & $\begin{array}{l}\text { 該考試是由授權筆譯員委員會 (the } \\
\text { Authorized Translators, Examination } \\
\text { Board) 組織實施。 }\end{array}$ \\
\hline & 英國 & $\begin{array}{l}\text { 翻譯文憑 (Diploma in Translation 簡稱 } \\
\text { DipTrans); 公共服務口譯 文憑 } \\
\text { (Diploma in Public Service interpreting } \\
\text { 簡稱 DPSI); 警務口譯文憑 (Diploma } \\
\text { in Police Interpreting 簡稱 DPl); 隻語 } \\
\text { 技能證書 (Certificate in Bilingual Skill } \\
\text {-s-Police 簡稱 CBS-Police); 商務語 } \\
\text { 言證書 ( Certificate in Languages for } \\
\text { Business 簡稱 CLB) }\end{array}$ & $\begin{array}{l}\text { 英國特許語言學會 } \\
\text { ( Chartered Institute of } \\
\text { Linguists, 以下簡稱 CI- } \\
\text { OL) }\end{array}$ & 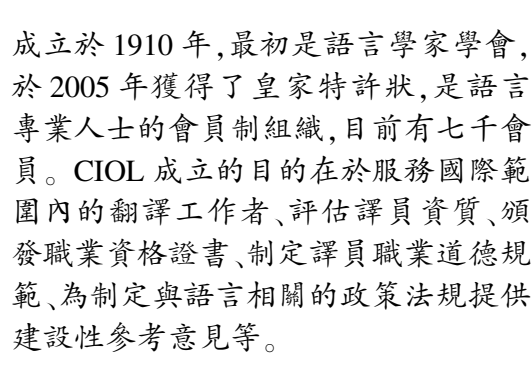 \\
\hline 非洲 & 南非 & $\begin{array}{l}\text { 翻譯;宣誓翻譯; 同聲傅譯(會議); 語 } \\
\text { 言編輯; 行語; 公司認證(僅通用於語 } \\
\text { 言辦公室) }\end{array}$ & $\begin{array}{l}\text { 南非翻譯協會 ( South } \\
\text { African Translators' In- } \\
\text { stitute, 簡稱 SATI) }\end{array}$ & $\begin{array}{l}\text { 作為南非翻譯領域影響力最大的專業 } \\
\text { 協會, SATI 認證體自 } 1990 \text { 年投入使 } \\
\text { 用, 市場認可度較高。 }\end{array}$ \\
\hline
\end{tabular}

表 110 個國家或地區翻譯資格(水準)考試資訊縱覽

\section{二、相同點和差異}

\section{（一）認證方式}

並非所有國家都使用相同的術語來指涉“認證”這一概念, 在澳大利亞, “認證” ( accreditation)一詞是指 通過考試或順利完成課程 (澳大利亞政府認可的學位、文憑或 NAATI 認可的海外課程) 的候選人,所獲得的 證書,新西蘭和南非也使用該詞。其他國家(如美國、加拿大、歐洲部分地區) 則使用 “鑒定” (certification)一 詞，“認證” 和“鑒定”這兩個詞的含義幾乎沒有區別,兩者都可以指 (官方) 授予個人或組織合格證書。然 而,這兩個術語之間的區別在於認證機構。在北美和歐洲國家, 向考生發出正式認可的認證機構隸屬於另 一個上層機構,該上層機構負責核查“鑒定機構” ( certify bodies) 發佈的“認證” ( accredit), 是否遵循了相關 標準。而這個更高的機構是“認證機構” ( accrediting body),對“鑒定機構” ( certifying body)進行授權。全國 翻譯專業資格(水準)考試(China Accreditation Test for Translators and Interpreters, 以下簡稱 CATTI) 是受人力 資源和社會保障部委託, 由中國外文局負責實施與管理的一項國家級職業資格考試,官方用的是“accredita- 
tion” (認證)，恰好印證了以上内容。在英國, “特許語言學家” (chartered linguist) 用來指英國皇家特許語言 學家協會 (Chartered Institute of Linguist) 的成員。而在南美, 法院則成為了正式認證機構, 常用 “宣誓” ( sworn) 這個專業術語來指代認證譯員。( Stejskal，2005) “......認證過程分為三種可能: 由專業協會認證; 由政府認證; 以及由學術機構認證。在英美法系國家, 專業協會的認證是最有力的, 而在大陸法系國家, 通 常採用政府機構認證;大陸法系國家和英美法系國家都設有學術課程,在政府或專業協會不提供認證的國 家中尤其如此”。在一些國家,通過考試僅代表你有從事翻譯工作的最低標準 (minimal requirement), 不代表 你就能獲得資格認證,具體情況見下表。

\begin{tabular}{|c|c|c|}
\hline 頒發機構 & 相同點 & 差異 \\
\hline 中國外文局 & \multirow{10}{*}{$\begin{array}{l}10 \text { 個國家或地 } \\
\text { 區的認證機構 } \\
\text { 均有考試認證 } \\
\text { 的形式, 部分認 } \\
\text { 證機構存在其 } \\
\text { 他認證方式。 }\end{array}$} & 以考試認證為主。 \\
\hline MOE & & 以考試認證為主。 \\
\hline NAATI & & $\begin{array}{l}\text { 獲得 NAATI 認證有五種方法: } 1 \text {. 通過 NAATI 考試; } 2 \text {.順利完成 NAATI 認可的筆譯和/ } \\
\text { 或口譯課程 ( TAFE1 文憑或大學本科或研究生學位); } 3 \text {. 通過提供 NAATI 認可的海外 } \\
\text { 資格證書; } 4 \text {. 具有國際公認的翻譯協會的會員證明 (例如 AIIC); } \text {. 具備高水準口筆譯能 } \\
\text { 力證明,NAATI 有一種語言 “識別”系統, 無須進行測試 } 1 \text { 。 }\end{array}$ \\
\hline ATA & & 以考試認證為主。 \\
\hline CTTIC & & $\begin{array}{l}\text { 三種認證方式:檔案認證( On Dossier Certification)、導師認證 (certification by mentor- } \\
\text { ship)、認證考試 ( certification examination)。目前只有鬼北克 ( Quebec) 和新不倫瑞克 } \\
\text { (New Brunswick) 提供導師認證 }{ }^{2} \text { 。 }\end{array}$ \\
\hline ITIA & & 考試方式認證只針對該協會會員。 \\
\hline AACI & & 以考試認證為主。 \\
\hline EDUFI & & $\begin{array}{l}\text { 申請人通過授權翻譯員考試( the Authorized Translator's Examination) 或獲得翻譯専業 } \\
\text { 碩士學位後,芬蘭國家教育局( Finnish National Agency for Education)授予譯員合法進 } \\
\text { 行翻譯工作的權利。 }\end{array}$ \\
\hline CIOL & & 以考試為主要認證方式。 \\
\hline SATI & & 該考試認證系統只面向該協會會員且只能通過考試合格獲得資格認證。 \\
\hline
\end{tabular}

表 2 認證方式異同

\section{（二）報考條件}

\begin{tabular}{|c|c|c|}
\hline 頒發機構 & 相同點 & 差異 \\
\hline 中國外文局 & \multirow{5}{*}{$\begin{array}{l}\text { 大部分國家或 } \\
\text { 地區考生參加 } \\
\text { 考試前需要具 } \\
\text { 備學歷背景、工 } \\
\text { 作經歷或成為 } \\
\text { 翻譯協會註冊 } \\
\text { 會員等方面的 } \\
\text { 要求。 }\end{array}$} & 無限制 \\
\hline MOE & & 報考筆譯無限制, 口譯考試筆試測試通過之後,方可進行口譯測試。 \\
\hline NAATI & & $\begin{array}{l}\text { 考生須通過語言能力測試、職業道德和跨文化能力測試, 各級別的考試均對學歷、翻譯 } \\
\text { 工作經歷有要求。 }\end{array}$ \\
\hline ATA & & 任何人都可參加考試,唯一規定是申請者需在考試前至少兩周成為 ATA 註冊會員。 \\
\hline CTTIC & & $\begin{array}{l}\text { CTTIC 由 } 7 \text { 個成員機構組成,必須是成員機構的會員才有資格報考,且面向經驗豐富的 } \\
\text { 譯員 (experienced translators)。 }\end{array}$ \\
\hline
\end{tabular}


续表

\begin{tabular}{|c|c|c|}
\hline 頒發機構 & 相同點 & 差異 \\
\hline ITIA & \multirow{5}{*}{$\begin{array}{l}\text { 大部分國家或 } \\
\text { 地區考生参加 } \\
\text { 考試前需要具 } \\
\text { 備學歷背景、工 } \\
\text { 作經歷或成為 } \\
\text { 翻譯㙝會註冊 } \\
\text { 會員等方面的 } \\
\text { 要求。 }\end{array}$} & $\begin{array}{l}\text { 專門從事法律翻譯的 ITIA 専業會員要想成為 ITIA 認證的法律翻譯譯員 (ITIA } \\
\text { Certified Legal Translator), 申請人必須已經是 ITIA 専業會 ( ITIA membership categor) } \\
\text { or Professional ITIA Member), 具有 } 5 \text { 年的翻譯從業經驗, 並且有大量法律檔翻暲 } \\
\text { 經驗 }{ }^{3} \text { 。 }\end{array}$ \\
\hline AACI & & $\begin{array}{l}\text { 具有口筆譯專業大學文憑的人必須提供兩年専業經驗的證明; 其他候選人必須證明其 } \\
\text { 具有五年的專業經驗,而這些工作經歷相關證明可由客户出具。 }\end{array}$ \\
\hline EDUFI & & 對於報名参加考試的考生没有任何考前要求。 \\
\hline $\mathrm{CIOL}$ & & 對考生没有要求。 \\
\hline SATI & & 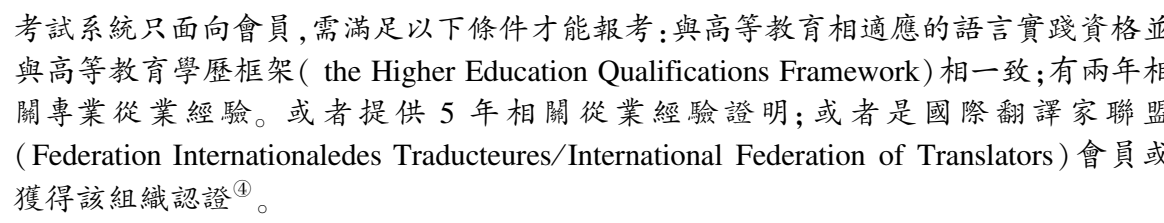 \\
\hline
\end{tabular}

表 3 報考條件異同

\section{（三）考試具體内容}

從考試題型和考試話題來看, 國内外翻譯水準測試各不相同。不過相同點也很明顯, 從各國所選材料 的文體特徵來看, 基本是應用型文體, 且都是主觀翻譯測試題——語篇翻譯題, 測試形式的設計與現實生活 中譯者能力高度相關,測試結果能較準確反映考生真實的翻譯能力。每個考生所掌握的話題知識結構不 同,有些話題對具有相關話題知識的考生來說相對容易, 而對其他考生來說較難, 因此話題知識設計也是影 響考生翻譯水準考試表現的因素之一。

\begin{tabular}{|c|c|c|}
\hline 頒發機構 & 相同點 & 差異 \\
\hline 中國外文局 & \multirow{4}{*}{$\begin{array}{l}\text { 都選擇用主觀 } \\
\text { 翻譯測試題,語 } \\
\text { 篇翻譯題是最 } \\
\text { 常見的題型。 }\end{array}$} & $\begin{array}{l}\text { 口筆譯考試均設有綜合能力和翻譯實務, 考試內容包括英譯漢與漢譯英兩類任務, 每類 } \\
\text { 任務均要求考生翻譯兩段文章, 考試大網對這四段文章的話題並沒有明確的規定。 }\end{array}$ \\
\hline MOE & & 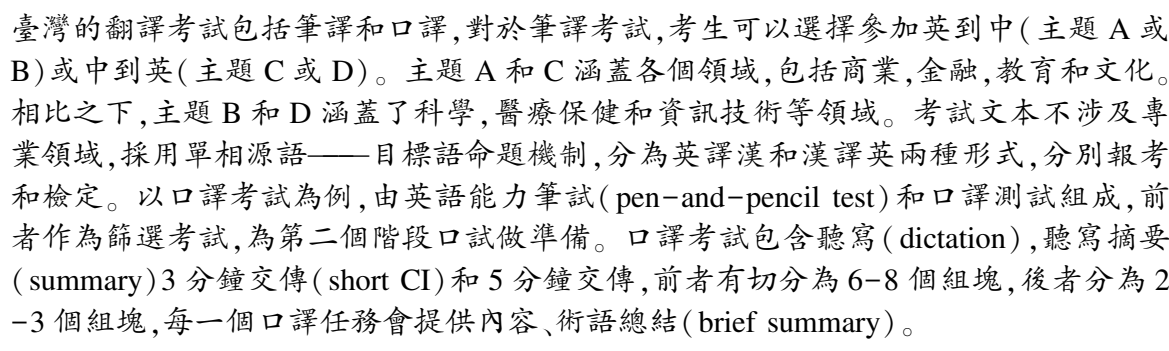 \\
\hline NAATI & & 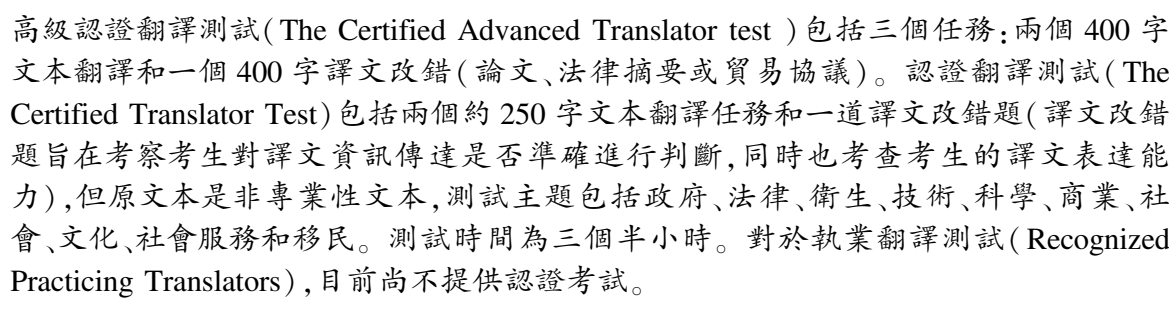 \\
\hline ATA & & $\begin{array}{l}\text { 以筆譯考試為例, 考生需完成三篇文章 ( } 225-275 \text { 字不等), 其中的兩篇是必須翻譯文 } \\
\text { 章,會特別避開尃業術語。每一篇文章都包含一個翻譯說明 (translation instructions), } \\
\text { 標明文本來源、翻譯目的、受眾, 以體現客户期待。 }\end{array}$ \\
\hline
\end{tabular}


续表

\begin{tabular}{|c|c|c|}
\hline 頒發機構 & 相同點 & 差異 \\
\hline CTTIC & \multirow{6}{*}{$\begin{array}{l}\text { 都選擇用主觀 } \\
\text { 翻譯測試題,語 } \\
\text { 篇翻譯題是最 } \\
\text { 常見的題型。 }\end{array}$} & $\begin{array}{l}\text { 考試要求考生翻譯兩篇文章,一篇是通用性題材,為必選題; 另外一篇需要從兩篇備選 } \\
\text { 文章中進行選擇,或偏科技、醫藥方向,或偏政治、經濟方向。 }\end{array}$ \\
\hline ITIA & & $\begin{array}{l}\text { 申請人需要完成兩類文本,即短文本和長文本。短文本包括出生證明或結婚證書, 而長 } \\
\text { 文本一般是較長的文檔(例如合同)、法院判決書、公證書中的摘錄內容。考生必須在 } \\
\text { 兩份試卷中都通過才能取得證書。值得注意的是這些考試所選文本是實際文檔的副 } \\
\text { 本, 出於機密的原因,名稱和其他標識詳細資訊已被刪除。這些檔反映了 ITIA 認證法 } \\
\text { 律翻譯員在實際工作場合面對的文本類型。檔的某部分, 文字可能難以辨認, 且印章部 } \\
\text { 分被遮蓋, 因為評估時會考慮申請人如何處理此類困難。 }\end{array}$ \\
\hline AACI & & $\begin{array}{l}\text { 考試包括書面和口語兩種形式,筆試主要測試候選人的語言能力和翻譯能力, 奥地利法 } \\
\text { 律制度以及外國法律制度的基礎知識。口語形式包括模擬法律場合下的交替傅譯(例 } \\
\text { 如,證人的聽證,對被告的訊問), 考試持續約 } 1.5 \text { 個小時)。 }\end{array}$ \\
\hline EDUFI & & $\begin{array}{l}\text { 考試共包括三個部分:基於專業實践能力的多項選擇測試 (45 分鐘); 法律和行政兩個 } \\
\text { 方向的文本翻譯( } 2 \text { 小時 } 45 \text { 分鐘); 由考生任選一個領域的文本翻譯(商業、經濟學、醫 } \\
\text { 學, 科技或教育; } 2 \text { 小時 } 45 \text { 分鐘( These Qualification Requirements for Authorized Transla- } \\
\text { tors' Examinations, 2012))。 }\end{array}$ \\
\hline CIOL & & $\begin{array}{l}\text { 考試分為三個部分, 第一部分為通用性題材翻譯,第二、第三部分均為半專業性題材翻 } \\
\text { 譯。其中,第二分的備選翻譯文本涉及技術、商務和文學三個専業方向,第三部分的 } \\
\text { 備選翻譯文本涉及自然科學、社會科學和法律三個専業方向; 在後兩個部分的考試中, } \\
\text { 考生均需要從備選翻譯文本中選擇一個文本進行翻譯。 }\end{array}$ \\
\hline SATI & & $\begin{array}{l}\text { 從 } 6 \text { 個文本中,任意選擇 } 3 \text { 個文本進行翻譯, 文本 } 1 \text { 是必翻文本,話題偏雜誌文章的風 } \\
\text { 格,其他 } 3 \text { 個任意選擇的文本話題偏商業、金融、法律、經濟、科學、醫藥、運動、環境、 } \\
\text { 地理。 }\end{array}$ \\
\hline
\end{tabular}

\section{表 4 考試内容異同}

\section{（四）翻譯品質的評估方法}

關於如何進行翻譯品質的評估,不同學者的看法各不相同。就目前國内外翻譯水準測試的品質評估模 式來看,筆者發現主要分為錯誤扣分法、標準參照模式(整體性評分方法和分析性評分方法) 兩大類,前者根 據錯誤的嚴重程度和分數扣分, 後者根據一定的評分標準給分,各國翻譯品質評估方法具體見下表。

\begin{tabular}{|c|c|c|}
\hline 頒發機構 & 相同點 & 差異 \\
\hline 中國外文局 & \multirow[b]{3}{*}{$\begin{array}{l}\text { 除中國尚未對 } \\
\text { 外公佈具體考 } \\
\text { 試評分標準外, } \\
\text { 其餘國家或地 } \\
\text { 區均有一套獨 } \\
\text { 立且對外公佈 } \\
\text { 的翻譯評分 } \\
\text { 體系。 }\end{array}$} & 官方公佈基本要求, 尚未公佈具體的譯文品質要求。 \\
\hline MOE & & $\begin{array}{l}\text { 標準參照模式, 提供評定量表, 以測試準確度 (accuracy) 和表達能力 (delivery) 為主, 前 } \\
\text { 者占 } 60 \% \text {, 後者占 } 40 \% \text {, 但是準確度必須達到 } 48 \text { 分, 表達能力達到最低分 } 32 \text { 分, 及格分 } \\
\text { 為 } 80 \text { 分, 才能通過考試(口筆譯測試皆是)。 }\end{array}$ \\
\hline NAATI & & 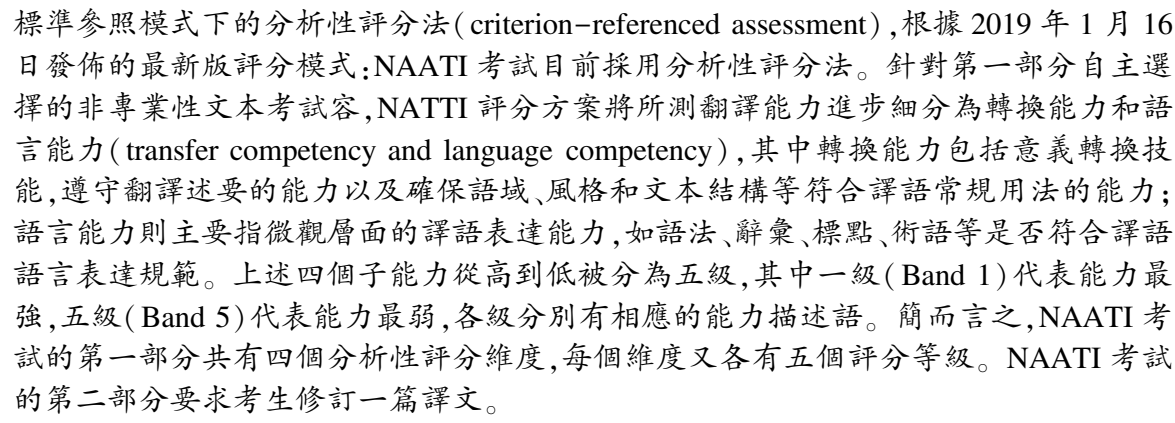 \\
\hline
\end{tabular}


续表

\begin{tabular}{|c|c|c|}
\hline 頒發機構 & 相同點 & 差異 \\
\hline ATA & \multirow{7}{*}{$\begin{array}{l}\text { 除中國尚未對 } \\
\text { 外公佈具體考 } \\
\text { 試評分標準外, } \\
\text { 其餘國家或地 } \\
\text { 區均有一套獨 } \\
\text { 立且對外公佈 } \\
\text { 的翻譯評分 } \\
\text { 體系。 }\end{array}$} & 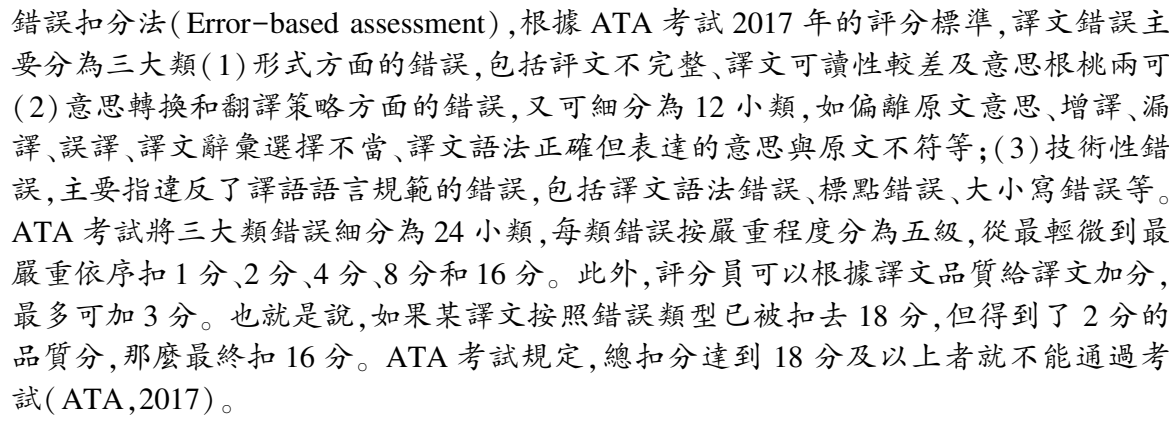 \\
\hline CTTIC & & $\begin{array}{l}\text { 錯誤扣分法 (Error-based assessment) ,錯誤被認為可分兩類:翻譯(理解-無法呈現原文 } \\
\text { 的意思)和語言 (表達一違反語法和其他目標語言使用規則)。 }\end{array}$ \\
\hline ITIA & & $\begin{array}{l}\text { 錯誤扣分法(Error-based assessment), 在打分標準方面, 如短文本 (出生/結婚/死亡證 } \\
\text { 明、文憑等)包含一個嚴重錯誤或 } 3 \text { 個輕微錯誤,則該測試為不合格等级。如果長文本 } \\
\text { (公司章程,律師函,合同等)包含一個嚴重錯誤或 } 5 \text { 個輕微錯誤,則該測試的等級為 } \\
\text { “不合格”。以嚴重錯誤的為例,包括理解錯誤、遺漏文字、専有名詞的拼寫錯誤、日期 } \\
\text { 錯誤、數據不正確; 輕微錯誤示例:標點錯誤、文字中非必要元素的拼寫錯誤、翻譯不貼 } \\
\text { 切、語氣處理不當。長文本和短文本皆合格,才能通過考核,如有一科未通過考試,下次 } \\
\text { 考試只考一科即可。 }\end{array}$ \\
\hline AACI & & 未作特殊說明。 \\
\hline EDUFI & & $\begin{array}{l}\text { 錯誤扣分法(Error analysis), 側重準確和流利度 (accuracy or adequacy, fluency), 提供 } \\
\text { 打分表 (scoring chart), 具體細分為內容 (C error)、可接受性和可讀性 (A errors)。分數 } \\
\text { 從 } 1 \text { 到 } 9 \text {,扣 } 9 \text { 分即為不及格,翻譯的目的、困難程度、考生考試所用時間最終也會算入 } \\
\text { 分數評估。考生會被告知考試評估系統是如何應用於考試文本, 並且在實際操作過程 } \\
\text { 中, 考生會收到一份打了分數的試卷副本,這樣有助於考生反思自己存在的問題, 䓡助 } \\
\text { 考生查漏補缺。 }\end{array}$ \\
\hline CIOL & & 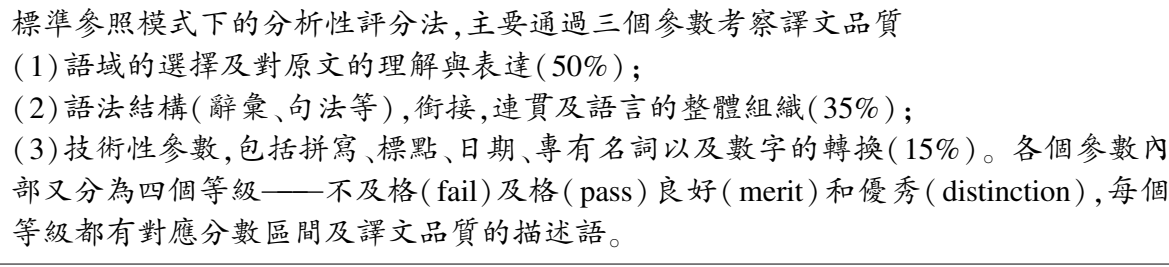 \\
\hline SATI & & $\begin{array}{l}\text { 錯誤扣分法 (Error-based assessment), 錯誤被分類為重大錯誤或輕微錯誤。一篇文本 } \\
\text { 中有 } 2 \text { 個或 } 2 \text { 個以上的重大錯誤,或者一個文本中的個重大錯誤和七個輕微錯誤, 意味 } \\
\text { 著沒有通過考試。重大錯誤和輕微錯誤定義如下:重大錯誤:嚴重誤譯, 其中原單詞或 } \\
\text { 短語的含義完全丢失; 遺漏重要詞語或資訊; 插入原文中未包含的資訊; 以及標語言 } \\
\text { 語法錯誤。輕微錯誤:歪曲原文意圖,但並非完全偽造的誤譯; 省略僅對原文有微影 } \\
\text { 響的詞語; 以及目標語言語法中的“不對等”。 }\end{array}$ \\
\hline
\end{tabular}

表 5 翻譯評估方法異同

\section{（五）考試使用工具}

考生使用工具的能力也是影響考生翻譯測試能力的重要因素之一, 比如考生資訊挖掘能力。翻譯水準 測試考察考生是否能根據翻譯任務要求選擇合適的翻譯輔助工具 ( 語料庫、電子詞典和術語庫), 技術能力 要求考生在翻譯過程中能較快有效地借助工具、軟體等輔助完成翻譯任務。各國翻譯水準考試具體使用工 具情況如下。 
Asia-Pacific Journal of Humanities and Social Sciences

\begin{tabular}{|c|c|c|}
\hline 頒發機構 & 相同點 & 差異 \\
\hline 中國外文局 & \multirow{10}{*}{$\begin{array}{l}\text { 均是開卷考試, } \\
\text { 對參考資料和 } \\
\text { 參考工具有一 } \\
\text { 定程度上的 } \\
\text { 限制。 }\end{array}$} & 機考,但是只允許攜帶 2 本紙質版詞典。 \\
\hline MOE & & $\begin{array}{l}\text { 機考和線下筆試相結合, 考生只能攜帶一本紙質詞典, 不得攜帶其他參考資料或電子 } \\
\text { 工具。 }\end{array}$ \\
\hline NAATI & & 考試過程中, 允許考生使用電腦和攜帶參考資料,但是禁止使用網路和與其他人溝通。 \\
\hline ATA & & $\begin{array}{l}\text { 兩種方式, 可線下筆試( pen \& paper) 或機考( online), 從 } 2015 \text { 年開始,開始提供機考,使 } \\
\text { 用自己的筆記本電腦,但是只可訪問電子詞典或詞庫網站,除此之外的内容, 比如互動 } \\
\text { 論壇,機器翻譯、社交媒體平臺是被禁止的。 }\end{array}$ \\
\hline CTTIC & & $\begin{array}{l}\text { 開卷考試,允許攜帶詞典和參考資料,被禁止攜帶的電子設備包括但不限於手機、寻呼 } \\
\text { 機、黑莓手機、iPod, 筆記本電腦和平板電腦, 另外不允許攜帶翻譯専業教科書。 }\end{array}$ \\
\hline ITIA & & $\begin{array}{l}\text { 考試文本通過電子郵件發送給考生。申請人就像在正常工作情况下一樣翻譯文本, 翻 } \\
\text { 譯工具可以使用電腦, 線上辭彙表等。考生在任何情况下均不應寻求第三方的幫助。 } \\
\text { 同時必須列出所有考試文本參考資料的具體來源, 並將其與翻譯後的文本一起提交。 }\end{array}$ \\
\hline AACI & & 未作特殊說明。 \\
\hline EDUFI & & $\begin{array}{l}\text { 考試過程中允許考生使用電腦和其他參考資料, 然而使用翻譯記憶庫( translation mem- } \\
\text { ory)、機器翻譯和郵件是被禁止的,也不允許和他人聯繫 }{ }^{5} \text { 。 }\end{array}$ \\
\hline CIOL & & $\begin{array}{l}\text { 機考和線下筆試兩種選擇,看考場實際情況,條件允許的話,也可選擇在家考試。可以 } \\
\text { 只用紙質的參考資料,如字典、詞典和辭彙表,在正式考試前考生要確認具體使用的參 } \\
\text { 考資料,考生不能使用網路資源, 電子詞典也是不被允許的 }{ }^{\circledR} 。\end{array}$ \\
\hline SATI & & $\begin{array}{l}\text { 在提前規定的考試日, 考生將通過電子郵件的方式收到考試文本 (受密碼保護), 並在 } \\
24 \text { 小時之內將翻譯後的文本以郵件的形式送回。考生允許使用以下工具: 目標語的拼 } \\
\text { 寫檢查器; 任何字典, 辭童表, 報告,語法指南; 辭典和語言書籍; 互聯網資源。 }\end{array}$ \\
\hline
\end{tabular}

\section{表 6 考試使用參考工具異同}

\section{（六）評分員任職資格(Assessor qualification)}

評分員要依靠自己的專業知識和專業判斷來評定翻譯品質, 這個過程中容易受到主觀因素的影響, 因 而影響效度,所以評分人員選拔層面,也是翻譯測試設計應重點考察的一個因素。

\begin{tabular}{|c|c|c|}
\hline 頒發機構 & 相同點 & 差異 \\
\hline 中國外文局 & \multirow{5}{*}{$\begin{array}{l}\text { 均對専業和評 } \\
\text { 分經驗一定 } \\
\text { 要求。 }\end{array}$} & $\begin{array}{l}\text { 翻譯資格考試的專家組成。共設有 } 10 \text { 個專家委員會,包括 } 9 \text { 個語種專家委員會和 } 1 \text { 個 } \\
\text { 高校促進委員會, 由近 } 300 \text { 名來自國內外政府機構、高校、企事業單位的權威專家組成。 } \\
\text { 此外, 翻譯資格考試由近千名專家組成的命審題和閱卷專家組。 }\end{array}$ \\
\hline & & $\begin{array}{l}\text { 評分員都是口譯員或者口譯培訓員, 在評分或教學領域有豐富經驗, 其中英到中評分 } \\
\text { 員, 母語是漢語, 中到英評分員以英語為母語,或者中英隻語。 }\end{array}$ \\
\hline MOE & & 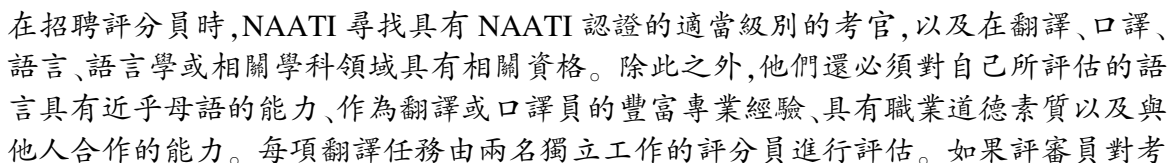 \\
\hline NAATI & & $\begin{array}{l}\text { 生的意見不一致,即他/她應該通過或者不通過, 這時就會寻求第三名評估員的協助 } \\
\text { (NAATI 2020g)。 }\end{array}$ \\
\hline ATA & & $\begin{array}{l}\text { 本著匿名、客觀和一致性原則, 試卷由兩名評分員打分, 如果對分數出現歧義, 則由第三 } \\
\text { 名評分員打分。評分者都是 ATA 資深認證譯員, 持續接受専業培訓和翻譯實踐, 遵守 } \\
\text { 評分標準。 }\end{array}$ \\
\hline
\end{tabular}


续表

\begin{tabular}{|c|c|c|}
\hline 頒發機構 & 相同點 & 差異 \\
\hline CTTIC & \multirow{6}{*}{$\begin{array}{l}\text { 均對専業和評 } \\
\text { 分經驗一定 } \\
\text { 要求。 }\end{array}$} & $\begin{array}{l}\text { 筆者没找到關於評分人員任職資格的相關資訊,但是 (Marker Guide, 2005) 明確指出: } \\
\text { 作為評分者,應收到以下檔: } \\
\text { 一 考試文本。 } \\
\text { 一 打分過後的試卷影本。 } \\
\text { 一 預先制定打分方案( Marking Scheme listing) } \\
\text { 一評分者指南。 } \\
\text { - 考試結果匯總表(Exam Results Summary Sheet), 未通過考試的申請者。 } \\
\text { 一 費用和開支表。 }\end{array}$ \\
\hline ITIA & & 未做特殊說明。 \\
\hline AACI & & 未做特殊說明。 \\
\hline EDUFI & & 碩士學歷、母語水準、評分員培訓。 \\
\hline CIOL & & 不對外公布評分人員具體資訊, 都是相關領域專家。 \\
\hline SATI & & 未做特殊說明。 \\
\hline
\end{tabular}

表 7 評分員任職資格情況

\section{（七）考前培訓}

考前培訓作為考生熟悉考試流程、考試形式和內容、考試難度和考後評估最重要的一環, 對翻譯測試設 計發揮至關重要的作用。

\begin{tabular}{|c|c|c|}
\hline 頒發機構 & 相同點 & 差異 \\
\hline \multirow[b]{3}{*}{ 中國外文局 } & \multirow{14}{*}{$\begin{array}{l}\text { 大部分國家或 } \\
\text { 地區的官方考 } \\
\text { 前培訓機構缺 } \\
\text { 少系統性組織 } \\
\text { 活動和執行 } \\
\text { 能力。 }\end{array}$} & 官方尚不提供官方培訓,但是提供官方教科書和樣題。 \\
\hline & & 官方未做特殊說明。 \\
\hline & & $\begin{array}{l}\text { 官網提供練習測試 ( practice text), 另外在每一個州和地區, NATTI 會開辦各種學習班 } \\
\text { 來幫助報考者成功通過考試從而獲得認證。學習班包括以下専案種類: 口譯強化訓練; } \\
\text { 道德和職業操守; 口譯筆記符號; 基礎口譯和筆譯技巧; 備考指南。 }\end{array}$ \\
\hline MOE & & \multirow{2}{*}{$\begin{array}{l}\text { ATA 在年度會議、研討會和其他活動中提供備考講習班, 組織網路研討會, 同時, ATA } \\
\text { 官方組織練習測試,測試打分均有官方評分人員完成。 }\end{array}$} \\
\hline NAATI & & \\
\hline ATA & & \multirow{2}{*}{$\begin{array}{l}\text { CTTIC 定期舉行會議,為來自加拿大各地的語言専業人士提供一個會面和討論國家問 } \\
\text { 題的機會; CTTIC 通過其成員機構促進考試通過人員的培訓, 這些機構與提供翻譯、術 } \\
\text { 語、口譯和相關領域課程的省级和地區教育機構合作。 }\end{array}$} \\
\hline CTTIC & & \\
\hline ITIA & & \multirow{3}{*}{$\begin{array}{l}\text { 和一些大學院校有合作培訓專案,比如都柏林城市大學應用語言和翻譯研究專業(BA } \\
\text { in Applied Language and Translation Studies in Dublin City University)、都柏林聖三一大 } \\
\text { 學( Trinity College Dublin)、愛爾蘭國立高威大學 ( National University of Ireland, Gal- } \\
\text { way)。 }\end{array}$} \\
\hline AACI & & \\
\hline EDUFI & & \\
\hline CIOL & & 未作特殊說明。 \\
\hline \multirow[t]{3}{*}{ SATI } & & 未作特殊說明。 \\
\hline & & $\begin{array}{l}\text { 一些獨立於 CIOL 的組織提供準備課程,但 CIOL 不為這些組織提供擔保,官方提供考 } \\
\text { 試卷子樣本,考生可通過官方管道申請;每個月 CIOL 官方會組織網路培訓。 }\end{array}$ \\
\hline & & 提供各種主題的網路研討會。 \\
\hline
\end{tabular}




\section{(八) 對考試結果進行申訴 (Appeal)}

對考試結果不滿意的考生可向上申訴,這將有助於提升考試信度,各國具體情況如下表。

\begin{tabular}{|c|c|c|}
\hline 頒發機構 & 相同點 & 差異 \\
\hline 中國外文局 & \multirow{10}{*}{$\begin{array}{l}\text { 目前只要極少 } \\
\text { 數國家或地區 } \\
\text { 認證機構開通 } \\
\text { 申訴制度。 }\end{array}$} & 尚不提供申訴制度。 \\
\hline MOE & & 未做特殊說明。 \\
\hline NAATI & & 考生可申請復查試卷, 若考試復查結果通過, 退還申訴費用。 \\
\hline ATA & & $\begin{array}{l}\text { 在接到考試成績 } 6 \text { 個月以內, 對考試成績懷有疑惑的考生, 可申請申訴, 請求從新審核 } \\
\text { 試卷分數,如果分數有誤,則會得到改正,如果評分人員依舊認為分數不合格, 則會發送 } \\
\text { 給考生一份詳細的報告, 向考生闡述分數不達標原因。 }\end{array}$ \\
\hline CTTIC & & $\begin{array}{l}\text { 未通過考試的考生可對其考試成績提出申訴, 從 } 2005 \text { 年開始, CTTIC 允許考生先提前 } \\
\text { 申請查看自己的試卷, 再決定是否要申訴。另外, 申訴要額外收費, 候選人的考試文本 } \\
\text { 交給第三位評分員, 如果申訴成功, 費用返給考生。 }\end{array}$ \\
\hline ITIA & & 未作特殊說明。 \\
\hline AACI & & 未作特殊說明。 \\
\hline EDUFI & & 考生對考試結果不滿意,有權利向考試委員會申辯。 \\
\hline CIOL & & 未做特殊說明。 \\
\hline SATI & & $\begin{array}{l}\text { 考試結果公佈之後的 } 8 \text { 周內, 考生可提交申訴表和付款證明, 如果“不及格”的結果被 } \\
\text { 推翻, 申訴費用將退回候選人, 並將被視為認證翻譯。 }\end{array}$ \\
\hline
\end{tabular}

\section{表 9 申訴情況}

\section{三、啟示}

相容並包, 廣納百家之長, 它山之石可以攻玉, 探索適合我國國情的翻譯資格水準考試制度, 筆者認為 可以從以下幾方面做出改變。

\section{（一）立體翻譯水準測試和認證體系}

我國應更大程度發揮中國翻譯協會的作用,建立政府引導、行業協會為主體、多方參與、協同管理翻譯 市場的立體化翻譯水準測試與認證體系。在組織考試、測試內容設計、培養和選拔人才方面,行業協會比較 瞭解市場需求, 不會造成嚴重的市場脫節; 行業協會可以和具體單位相結合, 比如英國、愛爾蘭、奧地利、美 國的法庭口譯員考試皆是和各州各地區法院合作, 這將有利於人才培養職業化和專業化發展。其次, 由翻 譯協會統一管理認證譯員資訊, 發佈工作需求, 和客戶建立鏈接, 管理魚龍混雜的翻譯市場, 尤其是價格市 場,有利於翻譯市場規範化發展。

\section{(二) 測試主題}

CATTI 是面向全社會的職業資格考試, 口筆譯考試均不使用特定領域 (如科技、商業、文學、法律、醫 療), 基本符合測試設計的通用性原則, 但是缺陷是不利於測量特定領域的翻譯人才 (楊志紅,2019)。中國 也缺少諸如編輯 (南非)、項目經理 (日本)、法庭口譯員 (奧地利、愛爾蘭、美國、加拿大)、公共醫療口譯 (英 國)。新冠肺炎疫情全球突發的情況下, 建立緊急語言服務體系從 CATTI 專業認證體系人手具有實際操作 意義, 中國因此也有必要加相關專案的職業化人才考試, 比如醫療口筆譯、法庭口筆譯認證考試。翻譯水準 
測試旨在考查學生在真實世界中的翻譯水準, 所以考試所選文本應注重真實性。CATTI 在設計此類題型時, 可以提供一個翻譯材料情景描述 (可參考表 4), 用於說明譯文的使用情景、目標讀者等資訊, 而這也會方便 考生根據目標讀者群體和譯文目的選擇翻譯策略和語域。此外, 翻譯歸根結底是為交際活動服務的, 總在 一定交際情景下發生,有鑒於此,CATTI 測試主題設計應更加側重實用性、市場性, 充分體現交際性特徵, 使 其適用於真實的翻譯任務情景 (例如, ITIA 採用的是真實文本, 並把關鍵資訊模糊化)。所以翻譯測試如何 反映真實場景下的應用, 是測試設計者值得思考的一個問題。

\section{（三）考試評估}

CTTIC 和 ATA 官網有詳細的打分指南、評估標準及扣分流程,這方面值得 CATTI 學習,進一步探索適合 中國國情的考試評估模式。中國每年參加翻譯資格證考生眾多, 考試測試評分細則要方便操作還要兼顧公 平, 這冊庸置疑會有一定難度。NATTI 於 2012 年委託第三方做了翻譯資格水準測試的改革發展報告 ( Hale et al.2012)。EDUFI 也組織了專業團隊, 進一步簡化評分標準( Kivilehto, 2017)。CATTI 也可以由相關專家 引領帶隊, 研究評分方法, 挖掘適合中國國情, 服務於中國翻譯市場, 提升測評效率的評分體系。為了保證 評估的公平性, 評估標準應該透明和一致, 使考生知道評估系統的具體操作, 有利於考生提升翻譯方面的自 我評價和自主學習能力, 但 CATTI 並沒有公佈評估標準, 因此, CATTI 應積極探索適合中國考試國情的評估 標準,並公佈詳細的評估標準。

\section{（四）官方備考指南}

筆者所指的官方備考指南包括線上線下官方培訓、考前官方推出的樣題及練習測試 (practice test) 和出 具的診斷性報告及考後公佈結果時的診斷報告。首先在考試認證前, 由官方組織的培訓或練習測試, 可幫 助考生熟悉考試流程, 考試難度和形式。尤其是考前練習測試中, 官方給出的詳細回饋報告可幫助考生查 漏補缺, 順利完成備考及通過考試。這一點可借鑒美國 ATA 的做法 ( 缺點是 ATA 報名費用為 525 美元, 練 習考試費用為會員 80 美元, 非會員 120 美元, 費用偏高), CATTI 官方可找一個折中的辦法, 比如只針對申訴 的考生。如若考生對考評結果不滿意, 可以向 CATTI 管理部門 (中國外文局) 申訴, 並有權要求 CATTI 管理 部門重新評估試卷, 且考生收到的評估結果應包含具體的考試資訊回饋, 即對試卷的每個部分進行單獨且 詳細的診斷性報告或評估回饋。診斷報告有助於考生對譯文進行反思, 從而提升自主學習能力。另外, 中 國外文局發揮主體地位, 中國翻譯協會和各地區成員協會負責的培訓體系也至關重要, 中國外文局可與各 省市各地區有能力有資格的培訓機構合作, 舉行官方培訓, 提升考試通過率, 這方面可向 CTTIC 學習 (具體 情況見表 8)。

\section{（五）考試使用工具}

在人工智慧時代, 熟練使用各種工具的口譯員, 其綜合服務能力通常要高於不會使用工具的譯員。具 備良好資訊素養, 熟練使用口譯技術和工具解決口譯問題的能力成為現代口譯員必備的基本素飬 (王華樹, 2020)。口筆譯譯員提升資訊技術素養在人工智慧時代無可厚非, 培養譯員關注資訊技術素養的意識, 鍛煉 其使用資訊技術能力迫在眉睫。CATTI 測試設計者也應從該角度出發,設計有利於提升考生資訊技術素飬 的考試形式。CATTI《二筆實務》基本要求中明確提出英譯漢速度每小時 500-600 個單詞, 漢譯英速度每小 時 300-400 個漢字。從這條基本要求來看, 考查學生的翻譯速度能力, 那麼從翻譯能力構念的角度看, 翻閱 紙質詞典則是一種干擾因素, 測試設計應該關注考生解決翻譯問題的能力, 資訊檢索和使用輔助翻譯工具 的能力, 而 ATA 允許考生自行攜帶筆記本電腦, 提前下載好電子詞典(見表 6), 這樣省去考生攜帶厚重的紙 質詞典的苦惱,也是 CATTI 可以借鑒的方法。 


\section{四、結語}

筆者通過對比分析 10 個國家或地區翻譯測試在認證方式、報考條件、品質評估方式、申訴、考試具體內 容、考試實用工具等方面的異同, 希望見微知萌, 我國翻譯專業資格(水準)考試能夠取得長足發展, 滿足中 國迅速發展的市場需求,選拔高層次翻譯人才。

\section{注釋}

(1) 参見 NATTI 官網具體詳情, https: //www.naati.com.au

(2) 参見 CTTIC 官網具體說明,http://cttic.org/

(3) 参見 ITIA 官網具體詳情,https://www.translatorsassociation.ie/

(4) 参見 SATI 官網具體詳情,https://www.translators.org.za/

(5) 参見 EDUFI 官網具體詳情,https://www.oph.fi/en

(6) 参見 CIOL 官網具體說明,https: //www.ciol.org.uk

\section{參考文獻}

(1) ATA (American Translators Association). ATA Certification Program Framework for Standardized Error Marking Version (2017). Available online: https://www.atanet.org/certification/Framework

(2) EDUFI ( The Finnish National Agency for Education). Qualification Requirements for Authorized Translators' Examinations 2012: Regulations and Guidelines. Available online: https://www.oph.fi/download

(3) Hale, et al. (2012). Improvements to NAATI Testing: Development of a conceptual overview for a new model for NAATI standards, testing and assessment. Available online: https://www.naati.com.au

(4) Kivilehto M \& Leena S. (2017). Assessing Assessment: The Authorized Translator's Examination in Finland. Linguistica Antverpensia, New Series: Themes in Translation Studies, 16: 57-70.

(5) NAATI (National Accreditation Authority for Translators and Interpreters). 2020f. Expression of Interest. NAATI Examiner Panels. Available online: https://www.naati.com.au

(6) Stejskal J. (2005). Survey of the FIT Committee for Information on the Status of the Translation \&-Interpretation Profession. Available online: http://www.fiteurope.org

(7) 段兆會、張允:《國内外不同翻譯職業資格證書比較研究》,《考試研究》2018 年第 3 期, 頁 82-86。

(8) 段兆會:《翻譯職業資格考試内容設計研究》,天津商業大學學位論文 2019 年版。

(9) 馮芳:《國内外主要翻譯測試對比研究及對我國翻譯測試的啟示》,西北大學學位論文 2014 年版。

(10) 江進林、文秋芳:《基於 Rasch 模型的翻譯測試效度研究》,《外語電化教學》2010 年第 1 期, 頁 14-18。

(11) 李雙、錢多秀:《世界各國翻譯資格考試研究: 回顧與展望》,《北京第二外國語學院學報》2016 年第 1 期,頁 59-63。

(12) 李欣:《翻譯測試的“結構效度”及其實現》,《東北大學學報(社會科學版)》2004 年第 3 期,頁 217-219.

(13) 牛寧:《澳大利亞與中國翻譯資格證書認證體系的對比分析及其啟示》,中國譯協科技翻譯委員會、廣東省翻譯協會第十四屆 全國科技翻譯研討會論文彙編,中國譯協科技翻譯委員會、廣東省翻譯協會:廣東省科學技術協會科技交流部 2011 年版。

(14) 任文:《中澳口譯水準考試及資格認證對比談》,《中國翻譯》2005 年第 1 期, 頁 62-66。

(15) 王華樹:《人工智慧時代口譯技術應用研究》, 知識產權出版社 2020 年版。

(16) 吳萍、崔啟亮:《CATTI 與 MTI 銜接的現狀、問題及對策》,《上海翻譯》2018 年第 1 期, 頁 45-50。

(17) 肖維青:《翻譯測試的評分員信度研究—-TEM8 翻譯專案評分員問卷調查記略》,《外語學刊》2011 年第 6 期,頁 115-119。

(18) 楊志紅:《翻譯測試與評估研究》,外語教學與研究出版社 2019 年版。

(19) 姚師平:《一項關於澳大利亞翻譯資格認證體系與翻譯人才培養的調研報告》,華東師範大學學位論文 2019 年版。

(20) 趙田園、穆雷:《基於國情和行業發展的翻譯證書考試體系構建》,《山東外語教學》2019 年第 6 期, 頁 113-122。

(21) 朱雀:《由 NAATI 考試看 CATTI 考試中倫理考察的長久缺失》,《安徽文學(下半月)》2018 年第 11 期, 頁 239-241。 